\title{
The Effectively Maintained Inequality Hypothesis and Socioeconomic Inequalities in the Greek Higher Education Sector
}

\author{
Iakovos Tsiplakides
}

Greek Ministry of Education

\begin{abstract}
In this paper we draw on the hypothesis of "Effectively Maintained Inequality" (EMI), which holds that inequalities in higher education concern differentiation as regards the institutions or study programmes which people from different socioeconomic backgrounds choose, rather than the difference between participating and non-participating. It is an important issue, as in modern knowledge and information societies, characterized by new methods of getting, processing and distributing information, higher education is important as a means of equipping people with the knowledge necessary to participate actively in them, for personal growth and national growth. It also impacts positively on social justice, equality of educational opportunity and can boost intergenerational social mobility. These potential benefits, however, are undermined by segregation within higher education. In this paper we present the findings of a research study that examined the breadth of segregation of the higher sector in Greece by socioeconomic background. Research findings indicate a correlation among cultural, social and financial capital and programme or institution, thus conforming the theory of "Effectively Maintained Inequality".
\end{abstract}

Keywords: higher education, expansion, social class, Effectively Maintained Inequality

\section{Introduction}

The transition from the industrial to the knowledge and information society means that the social and economic relationships are organized around the effective exploitation of information and knowledge. The widespread diffusion of modern technology has led to the emergence of a novel type of society in which the basis is knowledge and information and not material goods. This kind of society is characterized by new methods of getting, processing and distributing information (Kumar, 1998). This means that in modern knowledge and information societies a well-trained workforce is essential not only for personal growth, but also for national growth. This, in turn, entails that education, and in particular higher education, has an important role to play in equipping young people with the knowledge and skills necessary to participate in these societies.

After World War II in many countries the realization concerning the relationship between education and personal and national growth has led to initiatives aiming at raising the educational level of people. As far as higher education is concerned, in recent decades many countries have adopted policies that aim at increasing the percentage of young people who participate in higher education and widening access to higher education has become "an increasingly important aspect of educational policy" (Weedon, 2014:1). These policies and initiatives aim at providing incentives to young people to continue their studies beyond secondary education. In addition, policies for the widening of participation in higher education have targeted specific groups of prospective students. These groups include students from less privileged 
socioeconomic backgrounds (e.g. working-class students), ethnic minority students and mature students. In this framework, the term "widening participation refers to "activities and interventions aimed at creating an HE system that includes all who can benefit from it - people who might not otherwise view learning as an option, or who may be discouraged by social, cultural, economic or institutional barriers (Allen and Storan, 2005:3). As a result of these policies, more people than before enter higher education. For instance, in Britain and Sweden, the number of higher education students has almost doubled since the beginning of the 1990s (Johansson et al, 2005).

The justification that accompanies the policies for the expansion of participation in higher education has been framed, as we have seen, in terms of national economic growth and creating antagonistic economies. The official rhetoric has also been framed around issues of personal advancement. In this framework, participation in higher education is often linked to increased opportunities for a smooth transition to the labour market and upward social mobility.

Most importantly, however, it was thought that increased participation in higher education would result in a reduction in social class inequalities. If more people from lower socioeconomic groups were given the opportunity to participate in higher education, they would have increased educational opportunities and would be in a position to combat social exclusion. A university degree benefits individuals, since it "is associated with improved life chances across nearly all domains of life" (Luthra \& Flashman, 2017:2).

Research findings provide evidence that these optimistic expectations have not been confirmed and that social class inequalities have not substantially decreased as a result of widened higher education access. Researchers have argued that the increased access has provided more, but unequal opportunities. We may have witnessed an increase in participation in higher education, but this does not mean that we have widened access, since particular groups are still under-represented within higher education. This means that "young people from disadvantaged backgrounds remain significantly underrepresented in the undergraduate population, particularly within high-status institutions" (Jerrim, 2013:1). Young people from middle class continue to be at an advantage, due to their increased cultural, social and economic capital, which means that they are overrepresented in high status higher education institutions and departments. By contrast, working class students choose less prestigious higher education institutions and departments, often because of their performance in university entrance examinations.

In this framework, researchers have argued that socioeconomic inequality in education can be accounted for using the theory of 'Effectively Maintained Inequality' (EMI). As the theory is applied to tertiary education, it means that inequalities are an issue or differentiation as regards the institutions or "programmes of study pursued" (Lucas and Byrne, 2017) from people from different socioeconomic backgrounds, rather than the difference between participating and non-participating in tertiary education (Lucas, 2001). In essence, scholars argue that the EMI hypothesis can adequately explain socioeconomic inequalities in education, since "socioeconomic inequalities are 'maintained' by students from lower socioeconomic backgrounds taking less advantageous curricula influencing their post-school destinations" (Marks, 2013: 1635).

\section{Higher Education in Greece}

The debate about socioeconomic inequalities in higher education after its expansion in the last two decades has gained prominence in Greece in recent years. Researchers study the expansion of higher education in many countries, but they also take into consideration some unique characteristics of the Greek higher educational system, which is described as a highly restricted one (Gouvias, 1998). One characteristic is that entry to higher education institutions is based on the results obtained in the nationwide university entrance examinations at the end of upper-secondary education which are held at the end of every school year. The number of students admitted in higher education departments is determined by the Ministry of National Education and Religious Affairs (numerous clauses). The limited number of places available in high-status university departments and the high demand for these departments means that there is strong competition in the higher education entrance examinations (Kyriazis and Asderaki, 2008). In other words, many higher 
I. Tsiplakides, Adv.J Social Sci.; Vol. 2 Issue 1, pp: 23-31, May 2018

education applicants wish to study in prestigious higher education departments, such as the Medical Department or the Law School, but only those with the highest performance in the university entrance examinations will secure a place in them. Strong competition leads to widespread resort to private supplementary tutoring. Most upper-secondary school pupils receive out of school support in the form of private tutoring or organised courses in order to prepare for the nationwide examinations and ensure admission to higher education.

In accordance with many other countries, the expansion of higher education after in recent decades has brought to the fore the issue of inequalities in higher education. After the 1997 educational reform, the number of places in higher education has increased substantially. The tertiary education attainment rate in Greece is high, at $40.4 \%$ in 2015, which is above the EU average of $38.7 \%$ (European Commission, 2016). According to official statistics, in 1995 there were about 45,000 entrants to higher education, while in 2008 there were 86,736 entrants. In $1995,22.1 \%$ of young people aged 18-22 participated in higher education, while in 2002 the percentage was $45.5 \%$. Research studies show a persisting correlation between class and higher education choice of studies after the expansion of higher education, (Sianou-Kyrgiou and Tsiplakides, 2009, 2011). The representation of social classes in university subjects remains unequal. Elite university subjects with a high status in the academic hierarchy that lead to privileged occupational trajectories (e.g. medicine and law) are dominated by middle-class students, while working-class students choose less prestigious subjects.

Having described the framework of the educational system in Greece, we then present the research study we conducted.

\section{Research and Methods}

The literature review on the higher education sector after its expansion in the last decades led us to pose two main research questions:

a) Is the Greek higher education sector stratified by social class?

b) Are working class students underrepresented in high status higher education institutions and departments?

We decided to focus on the above research questions for the following reasons. First, a literature review shows that higher education is a highly stratified sector (Gerald and Haycock, 2006; Karen, 2007; Hoxby and Avery, 2009). Higher education is stratified in terms of selectivity, and returns to earned degrees, a phenomenon that is referred to as "institutional stratification" (Bastedo and Gumport, 2003; Posselt et al., 2012). This means that students from different socioeconomic groups attend different higher education institutions and courses of study. For example, middle class students usually attend high status university departments (such as the medical or the law school) which offer high labour market rewards. By contrast, working class students usually study in university departments that lead to occupational trajectories with limited material and symbolic benefits. Second, there is a lack of studies in Greece that examine the stratification in higher education after the expansion of participation in it.

Data was obtained from the Hellenic Statistical Authority (http://www.statistics.gr/en/home/) which collects data from all first-year students who enter higher education (Hellenic Statistical Authority, 2014). According to the Hellenic Statistical Authority (2014), the data collected concern tertiary education, which in Greece consists of two main parallel sectors. First, Universities, including all the universities, Polytechnic Schools and the Athens School of Fine Arts. Second, the Technical Sector including the Technological Educational Institutes and the Higher School of Pedagogic and Technical Education (Hellenic Statistical Authority, 2014). The survey on the technical sector also encompasses the Higher Ecclesiastical Academies, the Merchant Marine Academies, the Higher Schools for Services and the Artistic Schools (Hellenic Statistical Authority, 2014). In Greece there are 23 Universities and 15 Technological Educational Institutes, including the School of Pedagogical and Technological Education (Nuffic, 2015). The research findings are presented below. 


\section{Results}

The data we collected show that Greece has witnessed a massive expansion in the higher education sector, socioeconomic inequalities persist. This is attributed to the fact that higher education is stratified, since middle and working-class students attend different university departments. In the next part we present the findings in relation to level of father's education and occupation.

\subsection{Father's education}

A strong correlation between father's education level and distribution within the different university departments was found, as shown in Figure 1. More specifically, in the academic year 2014-15, 72.9\% of the students who attend the Medical School in the National and Kapodistrian University of Athens (NKUA) have a father who is either a higher education graduate or holds a postgraduate studies degree. For the same academic year, $68.4 \%$ of the students who attend the Law School in the National and Kapodistrian University of Athens have a father who is either a higher education graduate or holds a postgraduate studies degree. The percentage of the students who attend the Law School with a father who is a secondary education graduate is much lower, $26.9 \%$. In the highly sought after Dentistry Department, $72 \%$ of the students have a father who is either a higher education graduate or holds a postgraduate studies degree. The above data show that middle class students with high levels of cultural capital are overrepresented in high status university departments in Greece. For these students going to university and a high status department is part of a 'normal biography' (Ball et al, 2002) and going to university is a 'taken for granted' decision (Pugsley, 1998).

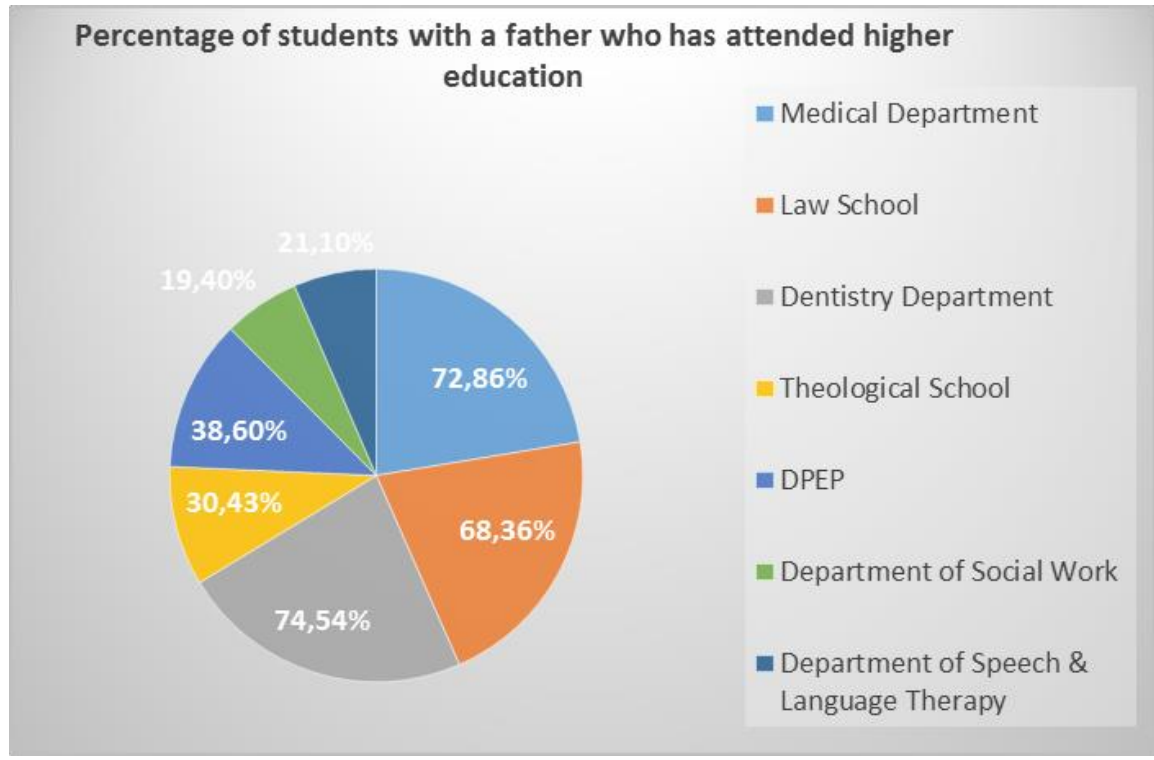

Figure 1: Percentage of students with a father who has attended higher education by University Department

By contrast, working class students seem to be overrepresented in lower status university departments (Figure 1). In the Theological School in the National and Kapodistrian University of Athens, $30.43 \%$ of the students have a father who is either a higher education graduate or holds a postgraduate studies degree. Similarly, 38.6\% of the students in the Department of Philosophy, Education and Psychology (DPEP) have a father who is either a higher education graduate or holds a postgraduate studies degree. Working class students usually attend Technological Education Institutions. These higher education institutions enroll students with lower levels of performance in the nationwide examinations for entrance in higher education. Since working class students usually have lower performance than middle class students, working class students have little choice (Johansson et al, 2005). The can only enroll in departments which do not require high entry qualifications. For instance, for the academic year 2014-15, in the Department of Social Work in the Technological Education Institute of Crete, the percentage of students with a father who is either a 
I. Tsiplakides, Adv.J Social Sci.; Vol. 2 Issue 1, pp: 23-31, May 2018

higher education graduate or holds a postgraduate studies degree is $19,4 \%$. For the same academic year, in the department of Department of Speech \& Language Therapy in the Technological Education Institute of Western Greece, the percentage of students with a father who is either a higher education graduate or holds a postgraduate studies degree is $21.1 \%$.

To sum up, these findings are in accordance with research findings that show that in England young people with professional/managerial parents are much more likely to enter a high status university than those with working class parents (Jerrim, 2013).

\subsection{Mother's Education}

A strong correlation between mother's education level and distribution within the different university departments was found, as shown in Figure 2. More specifically, in the academic year 2014-15, 71.31\% of the students who attend the Medical School in the National and Kapodistrian University of Athens (NKUA) have a mother who is either a higher education graduate or holds a postgraduate studies degree. For the same academic year, $65.02 \%$ of the students who attend the Law School in the National and Kapodistrian University of Athens have a mother who is either a higher education graduate or holds a postgraduate studies degree. The percentage of the students who attend the Law School with a father who is a secondary education graduate is much lower, $26.9 \%$. In the highly sought after Dentistry Department, $70 \%$ of the students have a mother who is either a higher education graduate or holds a postgraduate studies degree.

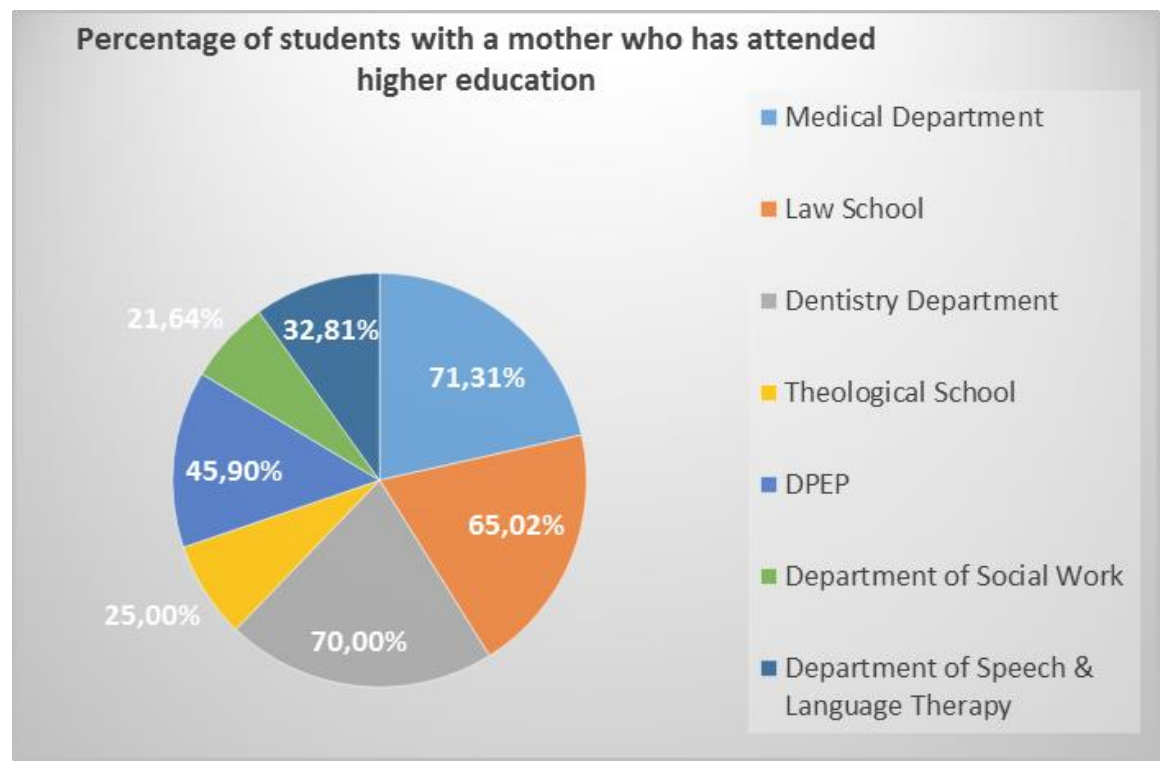

Figure 2: Percentage of students with a mother who has attended higher education by University Department

By contrast, working class students seem to be overrepresented in lower status university departments (Figure 2). In the Theological School in the National and Kapodistrian University of Athens, 25\% of the students have a mother who is either a higher education graduate or holds a postgraduate studies degree. Similarly, $45.9 \%$ of the students in the Department of Philosophy, Education and Psychology (DPEP) have a mother who is either a higher education graduate or holds a postgraduate studies degree. Working class students usually attend Technological Education Institutions. For the academic year 2014-15, in the Department of Social Work in the Technological Education Institute of Crete, the percentage of students with a mother who is either a higher education graduate or holds a postgraduate studies degree is $21.64 \%$. For the same academic year, in the department of Department of Speech \& Language Therapy in the Technological Education Institute of Western Greece, the percentage of students with a mother who is either a higher education graduate or holds a postgraduate studies degree is $32.81 \%$. 
The Effectively Maintained Inequality Hypothesis and Socioeconomic Inequalities in the Greek Higher Education Sector

It is also important to note that there are great differences among the above higher education departments concerning the performance level required to secure a place in them. More specifically, applicants who wished to enroll in the Medical School of the University of Athens needed to have a minimum grade of 19,063 points, out of a maximum of 20,000 points (academic year 2016-2017). The performance level required to secure a place in the higher education Schools and Departments presented above are shown below (Figure 3).

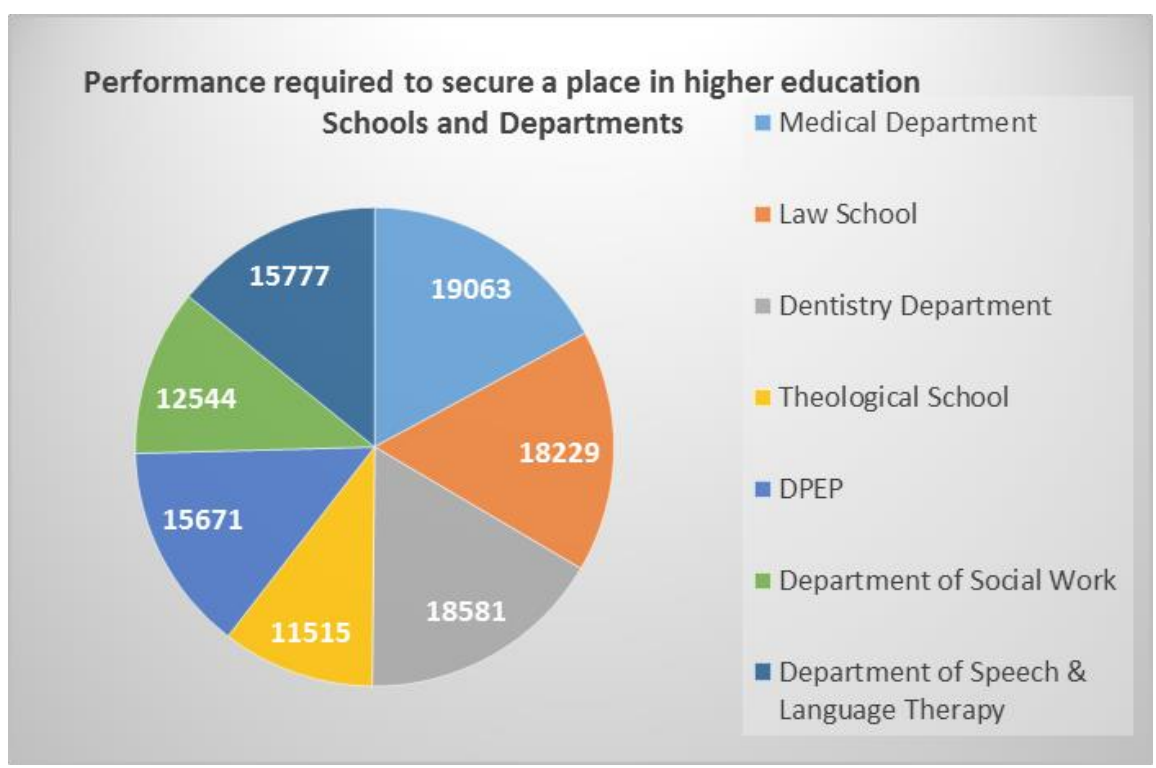

Figure 3: Performance required to secure a place in higher education Schools and Departments

The above Figure 3 shows that the higher education Schools and Departments in which students with parents with a higher level of education are overrepresented are those which require higher performance level in the university entrance examinations.

\section{Discussion}

Before discussing and analyzing the above results, it is important to accept a limitation of the research study. The fact that it uses only quantitative data must lead to a cautious assessment of the results. Employing a mixed methods approach, with quantitative along with qualitative methodology, could provide us with deeper insights into the issue under investigation (Denzin and Lincoln, 2008). This means that any conclusions and analyses are only tentative.

Despite the above caveat, the data described above shed light into the issue under investigation and allow us to answer the research questions. The first question we posed was whether the Greek higher education sector is segregated by social class. The data we collected provide strong evidence that the Greek higher education sector is segregated by social class. Students with parents who are higher education graduates or hold a postgraduate studies degree or come from professional backgrounds usually attend prestigious university departments such as the Medical or the Law School.

A close examination of the Greek educational system and the system for university entry can help us identify the reasons behind the unequal representation of people from different socioeconomic backgrounds in higher education departments. As we have already stated, entry to higher education departments in Greece depends on performance in higher education entry examinations. Research has already established that students from privileged socioeconomic backgrounds perform better than working class students (SianouKyrgiou and Tsiplakides, 2009, 2011). This means that the former have a wide array of higher education choices, so they usually choose high status departments. Similar findings have been observed in other countries. Research has shown that in Britain, "high GCSE grades was the main predictor in choosing highstatus and professionally-related courses such as medicine" (Ball et al, 2002). 
I. Tsiplakides, Adv.J Social Sci.; Vol. 2 Issue 1, pp: 23-31, May 2018

By contrast, working class students have lower performance levels in the higher education entry examinations. As a result, there are fewer choices available to them. This, in turn, means that if we are to tackle inequalities in higher education, we need to focus on inequalities, especially inequalities in relation to school performance, in lower levels of education (primary and secondary education). This is important, as research has shown that "children from disadvantaged backgrounds are much less likely to develop the advanced cognitive skills required to enter a high status university" (Jerrim, 2013:2).

The above findings have important consequences for the issue under discussion. In the past decades educational policies and initiatives in many countries aim at increasing the number of young people who study in higher education. At the same time, widening participation initiatives for groups of people who were underrepresented or excluded from higher education (such as working class, ethnic minority or mature students) have been introduced. As a result, the higher education sector has witnessed a significant expansion in many countries (Reay et al, 2005). More people than ever before enroll in higher education programmes of study (Walker and Zhu, 2008; Sianou-Kyrgiou and Tsiplakides, 2009).

According to the rhetoric accompanying these policies, the expansion of participation in higher education would improve the life chances of young people, increase inclusiveness, bring about equality of educational opportunity and boost upward social mobility. At the same time, the expansion of participation in higher education would also benefit countries, helping them to produce a highly skilled workforce necessary in modern knowledge and information societies. Official rhetoric also links the expansion of higher education with social justice, since, according to a "human capital" approach, there are positive associations between higher education, transition to the labour market and economic growth (Quinn, 2013; Shavit et al., 2007; Sianou-Kyrgiou and Tsiplakides, 2009, 2011). In this framework, it is assumed that there is a positive association between education and individual, economic, political and cultural development (Chabbott and Ramirez, 2000).

However, these optimistic expectations have not been met. Research findings indicate that inequalities persist and take other forms. An important reason for the persisting inequalities in higher education, despite the fact that more young people than ever before participate in it, is the distribution and stratification within higher education that has accompanied expanded higher education access. Students from privileged socioeconomic backgrounds are more likely to attend high status university departments (such as the medical school or the law school), while working class students usually study in university departments that lead to occupational trajectories with limited material and symbolic benefits.

To summarise the above observations, sociological research has consistently shown that the expansion of higher education has not been accompanied by a significant reduction in inequalities (Machin and Vignoles, 2004; Brooks, 2004). Most countries have not achieved an equal participation in higher education between groups with different social, cultural, economic and educational background. Research data reveal that the increase in participation in higher education has benefited mainly students from higher socioeconomic classes (Metcalf 1997; Pugsley, 2004; Connor and Dewson, 2001; Machin \& Vignoles, 2004; Iannelli 2007; Anders, 2012), in a highly stratified higher education sector (Ball, 2008).

Many researchers explain these persisting inequalities using Bourdieu's concept of cultural, social and economic capital as a mechanism of the dominant classes with the aim of maintaining their dominant position. In this framework, the students' cultural, social and economic capital impact strongly on success in higher education, since there is a connection between the unequally distributed cultural capital among students from different social classes and educational achievement (Bourdieu and Passeron 1977). In addition, the students' habitus, "a system of lasting, transposable dispositions which ... functions at every moment as a matrix of perceptions, appreciations, and actions", which is developed through experience, also affects the students' dispositions and behaviors in the higher education choice-making process (Bourdieu, 1977a:83). 


\section{Conclusions}

On the basis of the above discussion we conclude that the expansion of higher education cannot guarantee the widening of participation within it. The research results seem to confirm the 'Effectively Maintained Inequality' (EMI) hypothesis. We found that inequalities in higher education concern differentiation as regards the institutions or study programmes which people from different socioeconomic backgrounds choose, rather than in the difference between participating and non-participating in it. The findings provide evidence that students from more advantaged social class backgrounds are able to "secure for themselves qualitatively better kinds of education" (Boliver, 2011:229) and maintain their advantage.

Measures should be taken so that all students, regardless of socioeconomic background have educational qualifications that allow them to enroll at their preferred higher education departments, rather than those available to them due to their performance in university entrance examinations. In this framework, providing alternative progression pathways into higher education "based on vocational qualifications" (Johansson et al, 2005:18) could offer a viable alternative.

Future research should also focus on other factors that impact on social inequalities in higher education, such as success within it, student retention and graduation rates. It should also focus on differential patterns in the choice of study in higher education process which is "caused by different types of barriers: institutional, economic, social and cultural, and motivational" (Johansson et al, 2005:12) and "how the differential distribution of resources and skills influences learning" (Kettley, 2007:344).

\section{How to Cite this Article:}

Tsiplakides I. (2018, February 27). The Effectively Maintained Inequality Hypothesis and Socioeconomic Inequalities in the Greek Higher Education Sector. Advanced Journal of Social Science, 2(1), 23-31. doi: 10.21467/ajss.2.1.23-31

\section{References}

Allen, L., \& Storan, J. (2005), Widening Participation: A Rough Guide for Higher Education Providers, Bradford, University of Bradford. Anders, J. (2012), "The link between household income, university applications and university attendance", Fiscal Studies, 33(2), 185-210. Ball, S. J. (2008), The education debate: Policy and politics in the twenty-first century, Bristol, The Policy Press.

Ball, S. J., Davies, J., Miriam, D., \& Reay, D. (2002), “'Classification' and 'Judgement': social class and the 'cognitive structures' of choice of Higher Education", British Journal of Sociology of Education, 23(1), 51-72.

Bastedo, M. N., and Gumport, P. J. (2003), "Access to what? Mission differentiation and academic stratification in US public higher education", Higher Education, 46(3), 341-359.

Boliver, V. (2011). Expansion, differentiation, and the persistence of social class inequalities in British higher education, Higher Education, 61(3), 229-242.

Bourdieu, P., \& Passeron, J. C. (1977), Reproduction in education, society and culture, Beverly Hills, CA: Sage.

Brooks, R. (2004), “'My mum would be as pleased as punch if I actually went but my dad seems a bit more particular about it': parental involvement in young people's higher education choices", British Educational Research Journal, 30(4), 495-514.

Chabbott, C., \& Ramirez, F. O. (2000), "Development and Education”, in M. T. Hallinan (org.) Handbook of the Sociology of Education, New York, Springer, 163-187.

Connor, H., and Dewson, S. (2001), Social Class and Higher Education: Issues Affecting Decisions on Participation by Lower Social Class Groups. Research Report, No. 267. Institute for Employment Studies, Great Britain, Department for Education and Employment.

Croxford, L., \& Raffe, D. (2013). Differentiation and social segregation of UK higher education, 1996-2010. Oxford Review of Education, 39(2), 172-192.

Denzin, N. K., \& Lincoln, Y. S. (2008), Introduction: The Discipline and Practice of Qualitative Research. In N. K. Denzin and Y. S. Lincoln (eds.), Strategies of Qualitative Inquiry (pp. 1-44). Los Angeles: Sage Publications.

European Commission (2016). Education and Training Monitor, 2016. Greece. Available at: https://goo.gl/cW7z2A

Gerald, D., \& Haycock, K. (2006), Engines of inequality: Diminishing equity in the nation's premier public universities, Washington, DC, Education Trust.

Gouvias, D. (1998), "The Relation between Unequal Access to Higher Education and Labour-market Structure: the case of Greece", British Journal of Sociology of Education, 19(3), 305-333.

Hoxby, C. M., \& Avery, C. (2009), "The missing "one-offs": The hidden supply of high merit students for highly selective colleges", Paper presented at the American Economic Association annual meeting, San Francisco, CA.

Iannelli, C. (2007), "Inequalities in entry to higher education: A comparison over time between Scotland and England and Wales", Higher Education Quarterly, 61(3), 306-33.

Jerrim, J. (2013), Family background and access to 'high status' universities. Sutton Trust.

Johansson, M., Kim, L., Storan, J., \& Sorlin, S. (2015), Bridging the Gap: widening participation in Sweden and England. Stockholm and London. Swedish Institute for Studies in Education and Research and Continuum.

Hellenic Statistical Authority (2014). ELSTAT metadata. Available at: https://goo.gl/ZuXufF 
I. Tsiplakides, Adv. J Social Sci.; Vol. 2 Issue 1, pp: 23-31, May 2018

Karen, D. (2007), “Changes in Access to Higher Education in the United States, 1980-1992”, in A. R. Sadovnik (org.) Sociology of Education. A critical reader, New York, NY. Routledge, 251-265.

Kettley, N. (2007), “The Past, Present and Future of Widening Participation Research”, British Journal of Sociology of Education, 28(3), 333347.

Kumar, K. (1998), “The post-modern condition”, in A. Halsey, H. Lauder, P. Brown \& A. S. Wells (org.) Education, Culture, Economy, Society, Oxford and New York, Oxford University Press, 96-112.

Kyriazis, A., \& Asderaki, F. (2008), Higher education in Greece. Bucharest: UNESCOCEPES Monographs on Higher Education: European Centre for Higher Education.

Lucas, S. R. (2001), Effectively maintained inequality: educational transitions, track mobility and social background effects. American Journal of Sociology, 106(6), 1642-1690.

Lucas, S. R., \& Byrne, D. (2017), Effectively Maintained Inequality in Education: An Introduction, American Behavioral Scientist, 61(1), 37.

Luthra, R. R., \& Flashman, J. (2017), "Who Benefits Most from a University Degree? A Cross-National Comparison of Selection and Wage Returns in the US, UK, and Germany", Research in Higher Education, 1-36.

Nuffic (2015), The Greek education system described and compared with the Dutch system. Available at: https://goo.gl/bNWLyA

Machin, S., and Vignoles, A. (2004), "Educational inequality: The widening socio-economic gap", Fiscal Studies, 25(2), 107-28.

Marks, G. N. (2013), Evaluating Effectively Maintained Inequality: School and post-school transitions, socioeconomic background, academic ability and curricular placement. Social Science Research 42(6), 1635-1649.

Metcalf, H. (1997), Class and higher education: The participation of young people from lower social classes, London, CIHE.

Posselt, J. R., Jaquette, O., Bielby, R., \& Bastedo, M. (2012), “Access without equity: Longitudinal analyses of institutional stratification by race and ethnicity, 1972-2004", American Educational Research Journal, 49(6), 1074-1111.

Pugsley, L. (1998), "Throwing your brains at it: higher education, markets and choice", International Studies in Sociology of Education, 8(1), 71-90.

Pugsley, L. (2004), The university challenge, Aldershot, Ashgate.

Quinn, J. (2013), Drop-out and completion in higher education in Europe among students from under- represented group. An independent report authored for the European Commission, NESET, European Commission.

Reay, D., M.E. David, \& S. Ball (2005), Degrees of choice: Social class, race and gender in higher education, Stoke-on-Trent, Trentham Books.

Shavit, Y., Arum, R., \& Gamoran, A. (2007), Stratification in Higher Education: A Comparative Study. Social Inequality Series, Stanford, Stanford University Press.

Sianou-Kyrgiou E., \& Tsiplakides, I. (2009), "Choice and social class of Medical School students in Greece”, British Journal of Sociology of Education, 30(6), 727-740.

Sianou-Kyrgiou, E., \& Tsiplakides I. (2011), "Similar performance but different choices: social class and access to higher education in Greece", Studies in Higher Education, 36(1), 89-102.

Walker, I., \& Zhu, Y. (2008), "The College Wage Premium and the Expansion of Higher Education in the UK", Scandinavian Journal of Economics, 110(4), 695-709.

Weedon, E. (2014), Working Paper 1 - Widening participation to higher education of under-represented groups in Scotland: The challenges of using performance indicators, Edinburgh, University of Edinburgh.

Publish your research article in AIJR journals-

7 Online Submission and Tracking

8 Peer-Reviewed

9 Rapid decision

10 Immediate Publication after acceptance

11 Articles freely available online

12 Retain full copyright of your article.

Submit your article at journals.aijr.in
Publish your books with AIJR publisher-

1 Publish with ISBN and DOI.

2 Publish Thesis/Dissertation as Monograph.

3 Publish Book Monograph.

4 Publish Edited Volume/ Book.

5 Publish Conference Proceedings

6 Retain full copyright of your books.

Submit your manuscript at books.aijr.org 